\title{
Conceptual framework for describing the environmental impacts of waste accumulation due to intensive animal production
}

\section{Estrutura conceitual para descrição do impacto ambiental do acúmulo de dejetos da produção intensiva de animais}

\author{
Gladis Maria Backes Bühring ${ }^{1 *}$; Vicente Celestino Pires Silveira ${ }^{2}$; Claudio Rocha \\ de Miranda ${ }^{3}$; Eduardo Lando Bernardo ${ }^{4}$
}

\begin{abstract}
Highlights:
Framework based on DPSIR model, causal network, and ecosystem services was developed.

The conceptual framework was applicable to real conditions.

It assists in dealing with the waste from intensive animal production systems.

It identifies the drivers, main pressures, and impacts on the ecosystem services.

It contributes to the selection of indicators that reflect local conditions.
\end{abstract}

\begin{abstract}
The interaction between intensive animal production and the environment is complex and depends on the location and management practices. The waste generated from intensive animal production may represent a triggering factor for environmental pressures in the function of the volume and the characteristics, degrading environmental quality and affecting ecosystem services. The objective of this study was to develop a conceptual framework for the environmental description of the impacts caused by the accumulation of the waste from intensive animal production, integrating the causalchain approach of the driver-pressure-status-impact-response (DPSIR) model with the causal network and ecosystem services. Therefore, a conceptual framework was developed that makes possible a comprehensive description of a set of structures and functions that interact in complex ways. The conceptual framework was validated through a case study performed within the scope of a hydrographic microbasin with intensive pig production. The conceptual framework developed made it possible to establish connections among the DPSIR components, including environmental perceptions and changes in the socioeconomic system. The impacts caused by the waste were considered as changes in the provision of ecosystem services and the socioeconomic system, identifiable in the proposed conceptual framework. The application of the conceptual framework identified the primary drivers that exert pressure on the system and has an impact on the ecosystem services, affecting the provision and regulation services. The development of this environmental conceptual framework contributes to the selection of the indicators and ecosystem services involved. This can aid in the promotion of environmental sustainability, providing subsidies for more adequate environmental policies obtained from indicators that reflect local conditions.
\end{abstract}

Key words: Causal chain. DPSIR. Ecosystem services. Impact. Residual biomass.

${ }^{1}$ Dr $^{\mathrm{a}}$ em Extensão Rural, Departamento de Educação Agrícola e Extensão Rural, Universidade Federal de Santa Maria, UFSM, Santa Maria, RS, Brasil. E-mail: gmbackes@gmail.com

2 Prof. PhD, Departamento de Educação Agrícola e Extensão Rural, UFSM, Santa Maria, RS, Brasil. E-mail: vcpsilveira@gmail.com

3 Pesquisador, Empresa Brasileira de Pesquisa Agropecuária, EMBRAPA Suínos e Aves, Concórdia, SC, Brasil. E-mail: claudio. miranda@embrapa.br

4 Discente, Curso de Doutorado do Programa de Pós-Graduação em Engenharia Ambiental, Universidade Federal de Santa Catarina, UFSC, Florianópolis, SC, Brasil. E-mail: eduardolbernardo@gmail.com

* Author for correspondence 


\section{Resumo}

A interação entre a produção intensiva de animais com seu meio ambiente é complexa e depende principalmente da localização e das práticas de gestão. Os dejetos oriundos da produção intensiva de animais, em função do volume e características, podem representar um fator desencadeador de pressões sobre o ambiente, degradando a qualidade ambiental e impactando os serviços ecossistêmicos. O objetivo deste estudo é desenvolver uma estrutura conceitual para descrição ambiental dos impactos do acumulo de dejetos da produção intensiva de animais, integrando o enfoque de cadeia causal do modelo DrivePressure- Status- Impact- Response (DPSIR) com rede causal e serviços ecossistêmicos. Para tanto, foi desenvolvida uma estrutura conceitual, que permite descrever de forma abrangente um conjunto de estruturas e funções que interagem de maneira complexa. A validação da estrutura conceitual foi realizada por meio de sua aplicação em um estudo de caso realizado no âmbito da uma microbacia hidrográfica com produção intensiva de suínos. A estrutura conceitual desenvolvida permitiu estabelecer vinculação entre os componentes do DPSIR, incluindo percepções ambientais bem como de mudanças no sistema socioeconômico. Os impactos causados pelos dejetos podem ser entendidos como mudanças no fornecimento de serviços do ecossistema e no sistema socioeconômico, identificáveis na estrutura de análise conceitual proposta. A aplicação da estrutura conceitual identificou o principal driver que exerce pressões no sistema e que impactam nos serviços ecossistêmicos, afetando serviços de provisão e regulação. O desenvolvimento desta estrutura conceitual contribui para a seleção de indicadores e dos serviços ecossistêmicos envolvidos, que podem auxiliar na promoção da sustentabilidade ambiental, fornecendo subsídios para políticas ambientais mais adequadas, obtidas a partir de indicadores que reflitam as condições locais.

Palavras-chave: Biomassa residual. Cadeia causal. DPSIR. Impacto. Serviços Ecossistêmicos.

\section{Introduction}

Brazil is a major producer of agricultural commodities and animal protein, and the externalities of this production are not always considered. Livestock activities are sources of large quantities of waste and effluents in high concentrations with a high degree of pollution especially in pig farming. The large amount of waste produced represents residual biomass of a high organic load, which is considered an environmental liability with a potential negative impact on the environment if not properly managed.

With the increasing demand for food production, the environmental impacts of agricultural and livestock production have increased because of the rise in the number of animals, causing increased generation of concentrated waste in specific regions. In this context, an approach that considers the environmental and socioeconomic interactions can be used to identify the causes and dimensions of environmental issues. For this purpose, some methodologies are available, such as pressure-state-response, life cycle assessment, and driver-pressure-status-impact-response (DPSIR). However, for a better understanding of complex ecological processes and interactions between humans and the environment, DPSIR was used as a more complete model of environmental assessment and information.

The DPSIR model assists in the organization of structural indicators in the context of a causal chain that connects driver (D), pressure $(\mathrm{P})$, environmental state (S), impact (I), and social response (R) indicators. The driver indicators constitute the influences of human activities that cause changes in the environment. Pressure indicators describe the variables that directly cause or can cause environmental issues. The environmental state indicator shows the current conditions of the environment. The impact indicators describe the effects of condition changes. The social-response indicators describe societal entities (such as policies, regulations, and clean technologies) aimed at addressing the problems that feedback on $\mathrm{D}, \mathrm{P}$, 
and S, or even directly on I (Smeets \& Weterings, 1999; Niemeijer \& De Groot, 2008a; Kristensen, 2004). However, even though it is a structure used to describe the relationships between the origins and consequences of environmental issues, they are causal relations.

The DPSIR organizes the management strategies or responses, as well as the results or impacts, into indicator categories (Martin, Piscopo, Chintala, Gleason, \& Berry, 2018). These indicators can be used as tools for data synthesis and aggregation. Thus, it is important to establish a sequence of causes and effects of human actions, with appropriate indicators that show the condition of the system, considered as a set of interacting elements that are interdependent and mutually influencing (Von Bertalanffy, 2015). They also serve to verify the evolution of what occurs in the environment, to make it possible to adopt measures to promote environmental quality and continue to provide the ecosystem services necessary for development and welfare.

However, some authors have stated that the use of the causal chain is not conducive to a good understanding of the interrelationship of the indicators and the complex cause-and-effect relationships between drivers and the environmental impacts. Therefore, Niemeijer and De Groot (2008a) proposed an improved DPSIR framework (eDPSIR) inspired by systemic thinking that considers the complexities of the real world more effectively, using causal networks instead of causal chains. It is used as a structuring mechanism to select indicators.

A network-based causal framework includes the interrelationships of the many causal chains that interact. Therefore, a causal network can capture the full range of causes and effects and their interrelationships more effectively. These normally involve a large number of environmental indicators and traverse the boundaries of individual environmental issues (Niemeijer \& De Groot, 2008b).
Ecosystems provide a range of services that are fundamental to the welfare of people. These services are termed "ecosystem services" and can be considered as the benefits that human populations receive directly or indirectly from ecosystem structures and functions in combination with other production factors (De Groot, Fisher, \& Christie, 2010; Burkhard, Kroll, Nedkov, \& Müller, 2012a).

People benefit from ecosystem services (goods and services), such as nutrition, access to clean air and water, health, safety, leisure (Maes et al., 2016), and waste assimilation (Costanza et al., 1997), as well as services resulting from the functioning of ecosystems. Thus, changes in the ecosystem may have direct or indirect effects on the benefits and quality of life of the populations (Burkhard et al., 2012b). Therefore, ecosystem goods and services sustain human welfare. However, ecosystems are experiencing a range of degradations, and this, in turn, produces negative effects.

The human demand for ecosystem services has been increasing and demonstrates tradeoffs in its generation. Actions to increase food production involve an increase in the use of inputs and generation of waste and, often, an expansion of the cultivated area. In this sense, the pressures on the ecosystem can affect human health and welfare, becoming a challenge for the environmental management of production waste.

In this context, it is important to study the cause-and-effect relationship of animal waste in environmental systems, as well as to understand the impact of the waste on environmental change and how it affects the provision of local ecosystem services, their interactions, and their multiple effects. It is also important to consider the alternatives for reducing these impacts without compromising the delivery of other ecosystem services.

The panorama presented here portrays the environmental problems of intensive-animalproduction waste and how the interaction with the environment can cause changes in ecosystem 
services. Therefore, for a systemic understanding of these environmental issues, an attempt was made to integrate approaches and methodological references capable of demonstrating all the diverse relations and interrelations of cause and effect of this waste in environmental systems. To this end, the conceptual framework aims to organize and classify the indicators used for monitoring and evaluating the environmental and socioeconomic processes that permeate the issue of intensive animal production.

The definition of the conceptual framework took into consideration approaches with an analytical focus and with the possibility of empirical application. Therefore, the DPSIR framework was chosen because of its suitability for application in multidisciplinary tasks. The causal network was selected for its ability to describe the interrelationships of the various interacting and connecting causal chains. Ecosystem services were chosen for a broader view of the effects of human actions on the ecosystem and the consequences for human welfare.

The conceptual framework can be adapted in the context of environmental sustainability as a tool for describing and reporting complex interconnections and interactions between society and the environment, as well as orienting policy and decision making.

The objective of this work was to develop a conceptual framework for describing the environmental impact of the accumulation of waste from intensive animal production. Its empirical application in a case study in a hydrographic microbasin is described.

\section{Material and Methods}

The use of this methodology, which integrates the causal-chain framework of the DPSIR, the causal network, and the approach of the ecosystem services, makes it possible to organize and identify the main indicators associated with the environmental issue of the interaction of waste with the environment. Moreover, the methodology can be used to describe related aspects and to connect the socioeconomic and environmental factors to the ecosystem services.

\section{Establishing the conceptual framework}

Subsequent steps were established to develop the environmental conceptual framework.

\section{Definition of the interest domain and the limits of the studied system}

To define the interest domain, one must define the problem in a specific manner to maintain the network in a manageable way. It is also necessary to determine the underlying conditions to ascertain which aspects to consider and which to omit. It is also necessary to define the limits, predicting what will be included and what will be considered only regarding outputs and inputs.

\section{Proposition and selection of the indicators}

The indicators help to understand the more complex realities. Therefore, they are communication tools that help reduce the complexity of humanenvironmental systems (Kandziora, Burkhard, \& Müller, 2013). For each component of the DPSIR, components comprising the respective indicators were identified, and they are presented in a table.

The DPSIR framework has been recommended for studies on ecosystem service indicators, in which there is an enormous complexity with several components and bonds (Koschke, Fürst, Frank, \& Makeschin, 2012). However, what determines the level of accuracy of ecosystem service assessment and the respective data (and indicators) to be used must be the decision-making process (Scolozzi, Morri, \& Santolini, 2012). Therefore, comprehensive sets of indicators are necessary for a systemic and reproducible selection. 


\section{Establishment of the DPSIR framework}

An assessment methodology based on the DPSIR framework facilitates the integration of other models and consists of a tool based on the conceptual framework to demonstrate the changes caused in the environment by intensive animal production.

The DPSIR approach shows the cause-andeffect relationships of a given environment from the criteria segmentation and use of indicators to describe and quantify the individual components of the process, such as the following.

Drivers (D): These consist of several factors that can cause changes or drive the behavior of a system. The driver indicators describe the phenomena related to socioeconomic conditions, the current situation, and tendencies. They can be used as a basis to assess the system pressure that is, they describe the social, demographic, and economic developments in society and the corresponding changes in lifestyles, consumption, and production. Through these changes in production and consumption, the drivers can exert pressure on the environment (Gabrielson \& Bosch, 2003).

Pressure $(\mathrm{P})$ : Pressures are mainly a consequence of human-induced actions (Burkhard \& Müller, 2008), and they can be divided into excessive use of environmental resources, changes in land use, and emissions to air, water, and soil (Kristensen, 2004). In most cases, all human activities that affect the environment can be classified as pressures. However, the socioeconomic causes and effects of global change are highly varied and complex, and, because human pressures and actions are intimately connected, the pressures are more sensitive to changes and evolutions in the system (Zhou, Mueller, Burkhard, Cao, \& Hou, 2013).

State (S): Because the results of human actions are defined as pressures, the changes to physical, chemical, and biological environmental conditions are the state (Kristensen, 2004). To assess the environmental state in a holistic form, the processes (energy, matter, and water circulation) and components (species diversity and habitats) must be taken into consideration and integrated into an ecosystem-based approach (Zhou et al., 2013).

Impact (I): Changes in the environmental state affect welfare, which is closely related to an intact environment. Impact indicators are used to describe changes in the state of the environment (Gabrielson \& Bosch, 2003).

Responses (R): Responses arise as a consequence of specific problems, which influence drivers and pressures and can also improve the environmental state.

Identification and classification of the ecosystem services

After completing the previous steps, it is necessary to identify and classify the ecosystem services present in the DPSIR framework. The framework for defining ecosystem services adopted was developed by Common International Classification of Ecosystem Services (CICES) version 5.1, and it consists of three main service groups: provision, regulation and maintenance, and cultural services. CICES has become an important frame of reference for ecosystem service research, and this classification of ecosystem services has been used to provide a flexible and hierarchical tool that can be adapted and refined for specific situations and regional and local needs (Maes et al., 2016).

Provision services: Most provision services are described as water, genetic material, and biomass, and they refer to food, fiber, and energy. Provision services are considered easy to quantify through indicators (Dale \& Polasky, 2007), because they include tangible products.

Regulatory and maintenance services: These are the benefits people derive from the regulation that covers the transformation of biochemical or physical inputs into the ecosystems in the form of waste, toxic substances, and other inconveniences. 
They are the regulation of physical, chemical, and biological conditions. This categorizes the various forms in which living systems can mediate the physical, chemical, and biological environment in a beneficial way (Haines-Young \& Potschin, 2018).

Cultural services: These are the intangible benefits people receive from the ecosystems (Gee \& Burkhard, 2010) and, according to La Notte et al. (2017), are the services that are derived from the information.

Ecosystem services are highlighted in color in the conceptual framework.

\section{Establishment of the causal network}

The concept of the causal network follows the concept proposed by Niemeijer and De Groot (2008a), based on the idea of drivers and pressures leading to changes in the environmental state, which then create impacts that can cause social responses to regulate or change the pressures. The integration of the DPSIR with the causal network in the eDPSIR framework presented by Niemeijer and De Groot (2008a) considers all the interrelations among the indicators and not just those of a single causal line. Niemeijer and De Groot (2008a,b) recommended considering causal networks and the many causal chains that are interrelated within the networks. This concept is used here for the construction of the conceptual framework.

During this stage, the indicators established in the DPSIR framework are organized in a directional graph. In addition, the interrelationships of the indicators belonging to the driver components (D), the forces exerted by the pressures (P), the state $(\mathrm{S})$ of the variables in which the pressures are exerted, the resulting impacts (I), and the response mechanisms (R) developed, or the suggested responses, are mapped. The conceptual framework can be built and drawn in diagram software in this case, the draw.io free online software.
Fundamental nodes and identification of the associated indicators

The indicators are organized into categories according to the DPSIR logic and connected with arrows that demonstrate the directions of cause and effect. Through the interconnections between the framework indicators, the fundamental nodes are identified, as described by Niemeijer and De Groot (2008a): root nodes, central nodes, and end-of-chain nodes. Root nodes are those that have many outgoing arcs (arcs diverge from these nodes), and the indicators associated with root nodes are important, because they provide information about the sources of multiple environmental issues or problems (Niemeijer \& De Groot, 2008a). The central nodes are the nodes that have many input and/or output arcs (convergent and divergent arcs). These nodes are influenced by a number of factors and, in turn, influence a series of other indicators. These central nodes play an important role in the network of causes and effects and also have the characteristic that their indicators are at the root of several processes (Niemeijer \& De Groot, 2008a). End-of-chain nodes typically have multiple entry arcs (the arcs converge to these nodes) that assemble a series of longer chains and are located at the end of a series of cause-andeffect chains. These are typically the nodes where the effects of multiple pressures become visible (Niemeijer \& De Groot, 2008a).

The evaluation criterion used to identify the fundamental nodes is the sum of the input arcs and output arcs, not considering the quantitative weights of the indicators (Niemeijer \& De Groot, 2008a).

The use of this methodology, which integrates the DPSIR causal-chain framework, causal network, and approach to ecosystem services in a single framework, makes it possible to organize and identify the main indicators associated with the interaction, in the environmental problem, between the waste and the environment. It describes the related aspects and makes it possible to connect socioeconomic and environmental factors with the ecosystem services. 


\section{Case study}

The case study encompasses the hydrographic microbasin of Lajeado Clarimundo. It is located in the subbasin of Lajeado Fragosos and belongs to the Jacutinga River basin, in the municipality of Concórdia, Santa Catarina, Brazil, according to the location map in Figure 1. The municipality has a land area of $799 \mathrm{~km}^{2}$ (Instituto Brasileiro de Geografia e Estatística [IBGE], 2018) with one of the largest pork and poultry populations in the southern region of Brazil, as well as several agribusinesses focused on processing these products. The hog and poultry populations correspond to $20 \%$ and $13.6 \%$ of the total hog and poultry populations in the state of Santa Catarina, respectively (IBGE, 2018).
The focus of the application of the conceptual framework is the properties with intensive pig production. The data and indicators for the construction of the conceptual framework were obtained through the project developed by Embrapa Swine and Poultry "Evaluation of indicators and strategies for the valuation of environmental services in hydrographic basins with intensive animal production (SA-SuAve)," through a questionnaire applied in properties and referring to the productive and environmental aspects of pig farming, as well as the social and economic aspects.

The environmental and socioeconomic components and indicators were identified by the questionnaire, based on the authors' observations, without consulting the producers or other intervening actors.

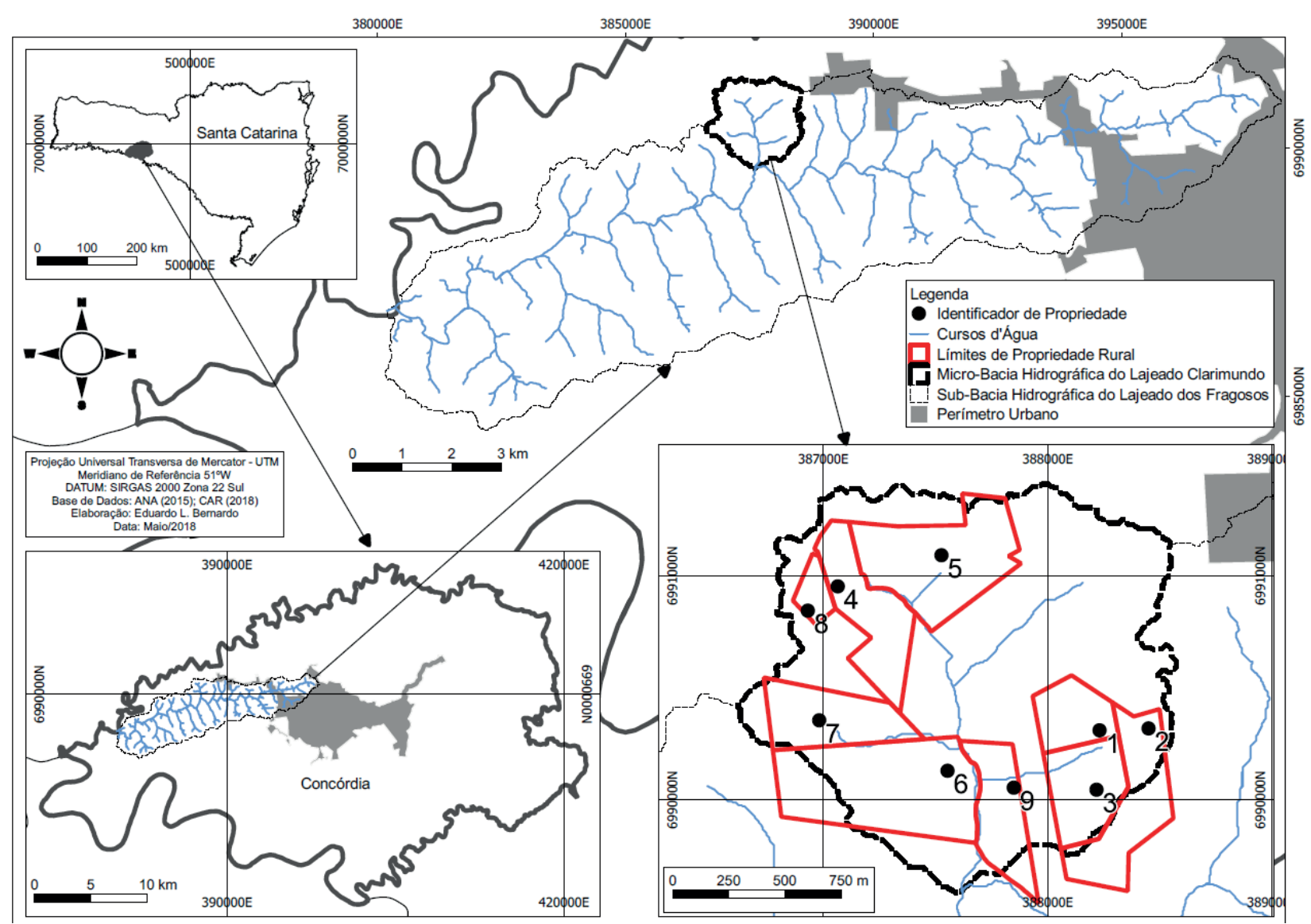

Figure 1. Location map of hydrographic microbasin of Lajeado Clarimundo. 


\section{Results and Discussion}

Approach to the environmental description conceptual framework

Intensive animal production can be considered a pressure that society exerts by using natural resources and emitting substances into the environment. This acknowledgment is important, because it is the mechanism by which the drivers exert pressure on the environment. Furthermore, it shows how different environmental issues interact and how different pressures can cause the same changes in the environmental state. It is possible to identify the various causes for each problem in the conceptual framework through the causal networks.

The DPSIR, as a conceptual basis, can order the relationships of the human environmental system. This presents high complexity, connections, and cause-and-effect relationships (Müller \& Burkhard, 2012). The fundamental question for using the causal network is the higher complexity of the environmental relationships when compared with the simple causal chains of the DPSIR framework (Niemeijer \& De Groot, 2008a). Thus, the use of causal networks, in which many causal chains interact, makes possible the incorporation of the multiple interactions observed in an intensive animal production system.

The environmental pressures of intensive animal production are a function of the level and technology applied. Therefore, the emission, use of resources, and land-use factors can reflect the technology variables used.

According to Müller and Burkhard (2012), drivers and pressures can cause impacts and damage the delivery of ecosystem services. Thus, the effects of animal waste can be considered to cause changes in the provision of ecosystem services and socioeconomic systems, identifiable in the conceptual framework.

The framework provides an integrative understanding of environmental and socioeconomic aspects and of the causal relationships of drives, pressures, state, ecosystem services, and impacts in an approach focusing on causal networks and the complex connections between indicators. The framework highlights key areas where indicators are essential to indicate the state of ecosystem services and identify the connections between the different elements of the study object. Thus, practical applications of this should make be possible by addressing waste from intensive animal production in a given system using appropriate sets of data and indicators.

Applying the conceptual framework to the case study of a microbasin

To verify the applicability of the environmental description conceptual framework, a case study was defined following the steps described in the methodology.

The domain of interest is the waste from the intensive pig production and its interaction with the environment. The demarcated limit consists of the nine pig production properties in the Lajeado Clarimundo hydrographic microbasin. These properties make up the system, with its elements in interaction as a reference for the analysis.

The quantitative details are unnecessary at this level of analysis, given that the specific application of this structure is precisely to describe the interactions of the different environmental issues and, perhaps more importantly, how multiple pressures can change the environmental and socioeconomic state, reverting into impacts.

Pig farming is the main activity in the properties. The waste storage system used is in reception pits, and the waste is destined to agricultural use with partial or total superficial application in crops and pastures.

To identify the pressure exerted by the generation of waste from pig activity, general information about the size of the population, the area with 
pig-farming properties, and the management of

the waste within the hydrographic microbasin of

Lajeado Clarimundo is presented in Table 1.

Table 1

Pressures exerted by pig farming in the study area

\begin{tabular}{lc}
\hline Information & Results \\
\hline Pig stock & 5.500 pigs \\
Waste volume & $38.7 \mathrm{~m}^{3}$ day $^{-1}$ \\
Water consumption & $66.8 \mathrm{~m}^{3}$ day $^{-1}$ \\
Area with pig-farming properties & $144.26 \mathrm{ha}$ \\
Total area of the hydrographic microbasin & $236.46 \mathrm{ha}$ \\
Area in the properties fit for waste disposal & $58.7 \mathrm{ha}$ \\
Waste cedency $^{5}$ & $179.9 \mathrm{ha}$ \\
\hline
\end{tabular}

Source: Elaborated from SA-SuAve (2018) and Fundação Do Meio Ambiente [FATMA] (2014).

Considering the pig stock and the area suitable for the disposal of waste, composed of pastures and temporary crops, with the storage system of waste in reception pits and the application of all waste in an area fit for waste disposal, the number of animals housed was calculated according to the annual demand for the nutrient limiting factor in agricultural areas. The reference nutrient was P2O5. The calculation was done according to the methodology presented by FATMA (2014). The crops considered were: year 1 , corn + winter pasture; year 2, corn + winter pasture; year 3, summer pasture + winter pasture; year 4 , corn + winter pasture. In these conditions, the number of animals housed would be 2,679 pigs in the finishing system; however, currently there is a group of 4,675 heads in this system, in addition to the rest of the population of the other production systems (in a total of 5,500 pigs), showing a surplus of waste in the microbasin.

However, there is the possibility of exporting surplus waste in cedency areas, adding, in this case, almost 180 ha in declarations of ceding contracts contained in the requirements for environmental licensing, for the distribution of waste in other properties with available agricultural area. Considering the suitable area for pig producers in the microbasin, the volume of application of waste would be approximately $240 \mathrm{~m}^{3} \mathrm{ha}^{-1}$ ano $^{-1}$. Adding the cedency area, the dosage would be $59 \mathrm{~m}^{3} \mathrm{ha}^{-1} \mathrm{ano}^{-1}$.

Managing animal waste is an environmental challenge because of the high volume and risk of water and air pollution (Fernandez-Lopez, LópezGonzález, Puig-Gamero, Valverde, \& SanchezSilva, 2016; Oudart, Robin, Paillat, \& Paul, 2015). Considering the specificities of the Lajeado Clarimundo microbasin and the technology used for applying the waste to the soil, the waste derived from the intensive pig production is a problem, mainly because of the lack of area for its application. The nutrients in the waste are unbalanced and present such residues as antibiotics and heavy metals. The waste management occurs in liquid form using a high volume of water, and the storage structures involve expenses and the emission of gas and unpleasant odors.

\footnotetext{
${ }^{5}$ Waste cedency is necessary when there is a deficit of agricultural area on the property for final disposal of the waste, and, therefore, it is necessary to assign the waste to third parties through ceding contracts.
} 
The classification of the environmental and pig-farming properties. According to the definition socioeconomic indicators presented in Table 2, given by Svarstad Petersen, Rothman, Siepel, and based on the DPSIR model, incorporates a systemic Wätzold (2008), the studied system is delimited perspective. This is implied in the demarcation of the system of interest limits, which encompasses the regarding the scale of the responses and drivers that affect the system.

Table 2

Components and indicators of the pig production in the DPSIR logic in the Lajeado Clarimundo hydrographic microbasin

\begin{tabular}{|c|c|c|c|c|c|c|c|}
\hline Problem & Components & Potential indicators & $\mathbf{D}$ & $\mathbf{P}$ & $\mathbf{S}$ & $\mathbf{I}$ & $\mathbf{R}$ \\
\hline \multirow{25}{*}{$\begin{array}{l}\text { Waste from } \\
\text { the intensive } \\
\text { pig produc- } \\
\text { tion }\end{array}$} & \multirow{5}{*}{$\begin{array}{l}\text { Conditions and } \\
\text { quality of life of } \\
\text { the farmers }\end{array}$} & Paid activity outside the property & & & & & \\
\hline & & Use of agricultural credit & & & & & \\
\hline & & Level of concern with the waste & & & & & \\
\hline & & Perspectives on pig production & & & & & \\
\hline & & Access to the Internet and telephone & & & & & \\
\hline & \multirow{6}{*}{ Soil use } & Total owned area & & & & & \\
\hline & & Leased from a third party & & & & & \\
\hline & & Total area for waste distribution & & & & & \\
\hline & & Soil use & & & & & \\
\hline & & Soil quality & & & & & \\
\hline & & Soil analysis & & & & & \\
\hline & \multirow{9}{*}{ Pig production } & Production system & & & & & \\
\hline & & Pig stock & & & & & \\
\hline & & Integrator agribusiness & & & & & \\
\hline & & Waste storage & & & & & \\
\hline & & Waste final destination & & & & & \\
\hline & & Waste cedency to third parties & & & & & \\
\hline & & Waste management & & & & & \\
\hline & & Dead animal destination & & & & & \\
\hline & & Waste management technologies & & & & & \\
\hline & \multirow{5}{*}{$\begin{array}{l}\text { Water and envi- } \\
\text { ronment }\end{array}$} & Environmental licensing & & & & & \\
\hline & & Water analysis & & & & & \\
\hline & & Water quality in the Lajeado Clarimundo & & & & & \\
\hline & & Pig-farming odor & & & & & \\
\hline & & Insect incidence & & & & & \\
\hline
\end{tabular}

\section{Drivers}

The integrating agribusiness is the main driver that conditions the pressures exerted by intensive pig farming directly on the environment. Although there are other drivers, such as the market demand for pork, incentive policies, available technologies, and the traditions of the pig farmers in the region, the integrating agribusiness was considered as a driver, because it is the local executor in the system, especially by fostering pig production. All the properties in this system have an integration contract with the agribusiness, because the agroindustrial 
contract is the primary governance structure in the main pig-producing regions of Brazil (Miele \& Waquil, 2007).

\section{Pressures}

The pressures are consequences of human activities that have the potential to generate adverse effects (impacts), such as the liberation of products, climate change, resource extraction and use, and land-use patterns (Omann, Stocker, \& Jäger, 2009). The identified indicators are the activities in the system related to pig farming that generate pressures in the human-environmental system responsible for assigning changes to the environmental state.

The area available to the pig farmer, including the areas owned and leased, which are added to compute the total area suitable for placing of the waste, is a pressure on the system, because the waste needs an area for its final disposal. When there is no agricultural area suitable for the application of the waste, i.e., compatible with the volume produced, there is a reduction of the stock according to the available area.

Land use corresponds to pressure on the system, mainly resulting from the use of natural resources and direct and indirect emissions to air, water, and soil.

The pig production system and the number of pigs in the establishment exert pressure on the environment through the volume of waste and the emissions of substances into the environment.

The storage of waste occurs in reception pits that must comply with current legislation. This places pressure on the system, because the loss of waste to the environment must be avoided.

The waste is used as organic fertilizer in crops and pastures. However, this final destination must be based on the dosage and application criteria for the soil. The amount of water and the nutrient imbalance in the waste, as well as the distances for application, make it difficult to use the waste as fertilizer.

Dead animals require proper disposal and are also pressure on the system.

Regarding the socioeconomic conditions and the quality of life of the farmers, the composition of the predominant workforce is the family, and there is a need to engage in paid activity outside the property. This is because the main productive system (pig farming) does not supply the expected level of income, and this is a strain on the system.

Another pressure is the need for the use of agricultural credit, because the productive system cannot generate enough income to invest in production.

Environmental licensing encompasses the legal environment for the environmental issue of pig farming, constituting legal requirements to prevent and correct the negative effects on the environment that may occur. Therefore, it is considered an indicator of the system that is, of the problematic nature of pig farming. However, environmental licensing can also be considered a pressure on the system, because it is mandatory for the installation, expansion, and operation of the pig-farming activity.

\section{State}

The environmental state describes the quality and conditions of the natural environment of the system.

The soil quality indicator refers to the interference in the soil's capacity to perform its functions as a consequence of waste disposal.

Changes in the quality of the water of the Lajeado Clarimundo microbasin caused by the drainage of the waste is another state indicator.

The odor indicator of pig production is related to air quality. 


\section{Impacts}

Derived from the state change, the impacts include socioeconomic impacts from environmental degradation. They describe the changes in environmental conditions caused or influenced by the intensive pig production in the system.

A related impact indicator is the need to conduct soil analysis to assess soil quality in areas to which waste has been applied over a long period.

Through water analysis, it is possible to identify variables resulting from the drainage of waste in the environment, such as water potability for human consumption, water eutrophication, and fish mortality.

The incidence of insects, such as flies and mosquitoes, is an impact derived from the excess organic matter of the waste in rivers and places with an accumulation of waste, and it can affect the health of the population.

When the system does not bear the volume of waste produced because of the lack of available area, it is essential to sign ceding contracts ${ }^{6}$ in third-party areas for the disposal of waste. This constitutes an impact indicator, because the system cannot support the waste produced and must export it.

\section{Responses}

Responses emerge in an attempt to prevent, compensate for, improve, or adapt to the changes in the environmental state in the system, to minimize pressures and improve environmental quality (Omann et al., 2009). Here, the responses from the system that are designed to improve the state and reduce the impacts are described.

The level of concern and awareness of the farmers regarding the environmental issue the waste presents is a response to a change in the environmental state of the system.
The prospects of the farmer to continue the activity of pig farming are a response that shows the degree of satisfaction in continuing the activity, as well as the existence or nonexistence of family succession in the system.

Regarding waste management, the difficulties can represent a response of the system for example, in the function of the volume and soil available for placing the waste.

The technologies used for waste management are a response to the system regarding the treatment processes, such as anaerobic digestion.

Environmental licensing is a response to the system's focus on environmental protection and recovery. Restrictions in the legislation regarding waste management and the emission of gases are important for the environmental control of this activity, conserving environmental resources in quantity and quality.

In summary, the context of the environmental issue of pig farming in the studied system refers mainly to the volume of waste produced in small areas that is, in a space insufficient to recycle the waste. The most accessible technological solution is the application of the waste to the soil. However, this generates excess waste in inappropriate places, contaminating the water and causing various problems.

\section{Ecosystem services}

With the DPSIR framework established, the classification of the ecosystem services is presented in Table 3.

The conceptual framework connects socioeconomic systems with environmental resources through the flow of ecosystem services and through the changes that affect them as a consequence of the use of these services or as

${ }^{6}$ A ceding contract is a formal area assignment contract for the distribution of pig waste, signed by the land donor and the pig producer. It has the purpose of proving the interest in the provision of area for application of pig organic fertilizer (Fatma, 2014). 
impacts derived from pig farming. Impacts on the system caused by the accumulation of waste from pig farming include changes in the provision of ecosystem services and the socioeconomic system (Müller \& Burkhard, 2012).

Many publications have reported the usefulness of the DPSIR as a scoping tool to conceptualize the interdependence in resource management problems
(Lewison et al., 2016), especially those that promote the concept of impact to include ecosystem services (Kelble et al., 2013). By including ecosystem services or the value that humans place on ecosystem services, the concept of impact captures a greater diversity of discourse by providing comprehensive information to decision makers (Kelble et al., 2013).

Table 3

Classification of the ecosystem services

\begin{tabular}{lll}
\hline Impacts on the system & Impacts of the ecosystem services & Examples of goods and benefits \\
\hline Soil quality analysis & $\begin{array}{l}\text { Physical, chemical, and biological } \\
\text { quality of the soil }\end{array}$ & $\begin{array}{l}\text { Maintenance of the soil quality and, } \\
\text { therefore, soil capacity for human use }\end{array}$ \\
\hline Water quality analysis & $\begin{array}{l}\text { Physical, chemical, and biological } \\
\text { conditions of the water }\end{array}$ & $\begin{array}{l}\text { Maintenance of the water quality, reduc- } \\
\text { tion of nutrient flow damage costs }\end{array}$ \\
\hline Insect incidence & $\begin{array}{l}\text { Accumulation of waste in the envi- } \\
\text { ronment }\end{array}$ & $\begin{array}{l}\text { Sustainable elimination of waste, disease } \\
\text { prevention }\end{array}$ \\
\hline Waste cedency to third parties & Biomass (waste) & $\begin{array}{l}\text { Use as organic fertilizer and for energy } \\
\text { production (biogas) }\end{array}$ \\
\hline
\end{tabular}

Key:

Regulation and maintenance ecosystem services

Provision ecosystem service.

As impacts occur through changes in ecosystem services, as stated by Kelble et al. (2013) and Elliott (2014), they are related to the impact component in the DPSIR framework. The ecosystem services identified are as follows.

a) Regulation and maintenance services: The analysis of water and soil quality is related to the maintenance of the physical, chemical, and biological quality of the soil and water that are affected by the waste disposed of without environmental control. Furthermore, it includes the proliferation of flies and mosquitoes caused by the accumulation of waste.

b) Provision services: The waste disposal to third parties is classified as a form of providing organic fertilizer, and there is the possibility of producing energy through biogas.
The driver identified in the DPSIR framework exerts pressures that have an impact on ecosystem services and may affect the provision and regulation in the system. The environmental problems arising from intensive animal production systems derive mainly from their geographic location and concentration, requiring adequate waste management with the objective of exporting and redistributing the excess nutrients with the locally accessible soil capacity to absorb this residue and optimize its recycling.

Interferences in the system often reduce the capacity of regulation services. However, the regulation of the environment is connected to a lower incidence of negative impacts. This means that an environment with efficient regulation services mitigates possible impacts resulting from the 
pressures in the environment. In other words, good environmental conditions in the system indicate a more balanced and resilient ecosystem that provides more services and maintains the capacity to provide them for the future.

\section{Construction of the conceptual framework}

In this stage, the causal network is established, in which the indicators are organized in a directional graph, and the interrelationships between the DPSIR indicators and the ecosystem services are mapped (Figure 2).

The use of the causal network makes it possible to distinguish the fundamental nodes of the proposed networks and to identify the main indicators that can be used to monitor and manage the sustainability of the system. Understanding how the status changes in response to human activities and their resulting pressures, identified by the nodes in the conceptual framework (pig stock, environmental licensing, storage and waste final destination, and total area for waste distribution), requires a conceptual basis that connects the causes and consequences of this change (Borja et al., 2016). The change in the state of the ecosystem can lead to changes in the supply of ecosystem services and, thus, in the services and the benefits obtained to society, while at the same time compromising the preservation of ecosystems themselves (Gómez et al., 2016), because of the pollution of soil and water by waste from intensive pig production.

The root nodes identified in the conceptual framework are the integrating agribusiness that drives the system, the environmental licensing, and the stock of pigs, which correspond to the sources of multiple effects. The identified central nodes correspond to the waste storage, the total area for waste disposal, the destination of the waste, and the water and soil quality. These factors are influenced by and influence many factors that can be the source of multiple problems. The end-of-chain nodes are the impact indicators. They correspond to the ecosystem services affected, such as the analysis of water and soil quality, the disposal of waste to third parties, and the incidence of insects. The responses in the conceptual framework correspond to the responses given by and to the system to avoid, compensate for, mitigate, or adapt to impacts.

The conceptual framework applied to the case study helped to identify the main factors that affect the system in the function of the waste from intensive pig production, showing the intermediate steps among the indicators and providing an important basis to establish response functions for this system. 


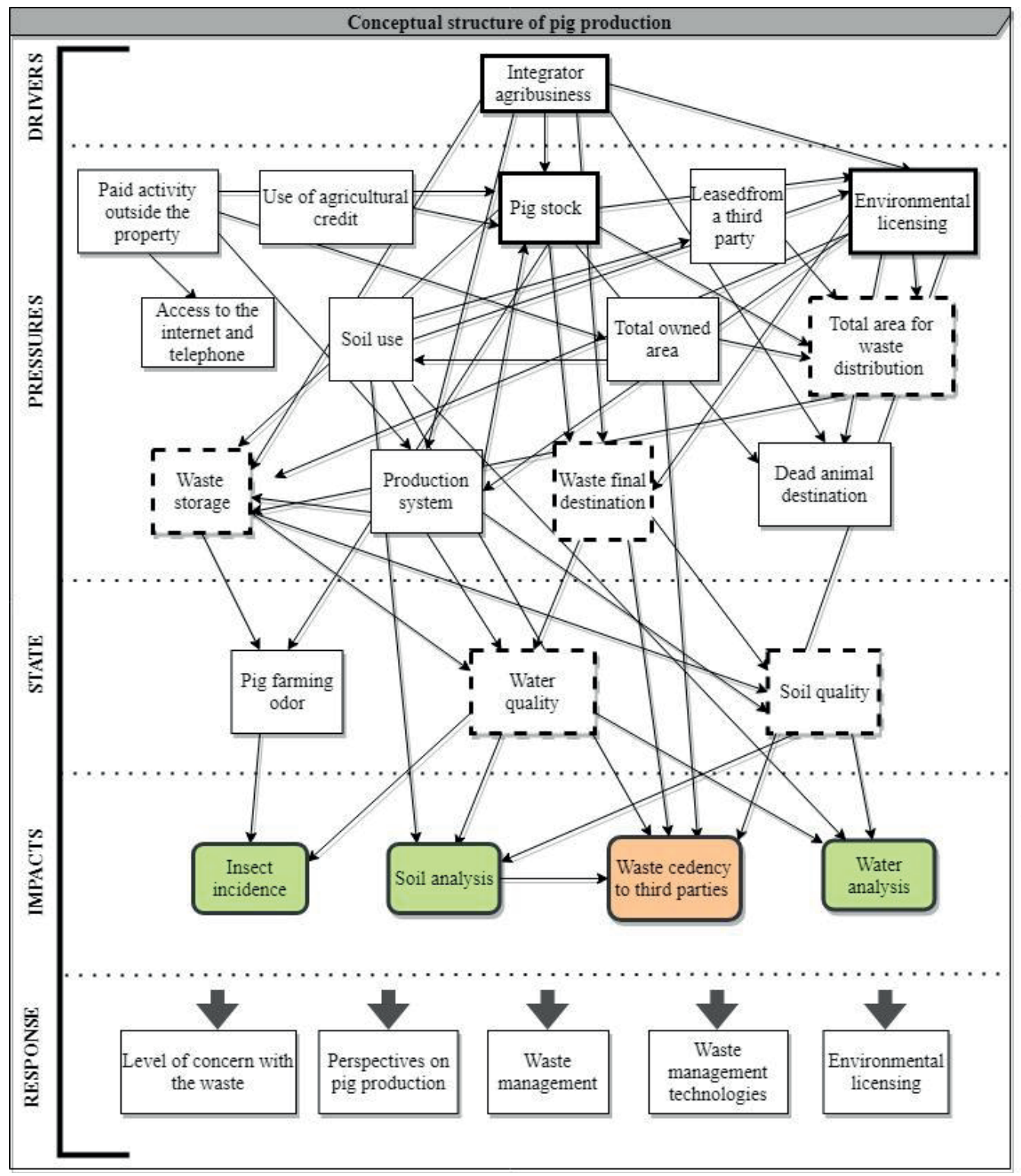

Key:

$\longrightarrow$ An arc shows a linkage and the direction of the effect of one node on another.
Root node

\begin{tabular}{|c|}
\hline ECOSYSTEM SERVICES \\
\hline Provisioning services \\
\hline Regulating and maintenance services \\
\hline
\end{tabular}

Figure 2. Conceptual framework applied to the case study. 


\section{Conclusions}

The primary challenge of this work was to produce a conceptual framework with real application conditions, considering the description of a system with its elements interacting. For this, a structure was proposed based on the DPSIR, which, through the interaction and inclusion of different cause-and-effect chains, is adaptable to changes.

The conceptual framework approach helps address the problem of the waste from intensive animal production systems, such as pig farming, in terms of environmental and socioeconomic issues, by identifying the main indicators and the impacting factors in the DPSIR model. These factors include the services of the ecosystem. To integrate human involvement and the consequent adaptation to environmental changes, the ecosystem services were integrated into the conceptual framework to capture the complexity of environmental problems more comprehensively. The intention in identifying the ecosystem services with the DPSIR and the causal network is mainly to understand ecosystem services regarding a set of cause-and-effect relationships.

The application of the conceptual framework in the case study provided an approach to identify the drivers, main pressures, and impacts of the studied system on the ecosystem services. Responses were assumed to reduce the environmental issues of the system, which was composed of the pigfarming properties in a hydrographic microbasin in conjunction with socioeconomic interactions. To combat the degradation of the ecosystems and work toward sustainability, the system must consider adaptations, such as technological changes, changes in human behavior, and the recovery of ecosystem services.

The results of applying the conceptual framework identified the main driver that exerts pressures on the system and has an impact on ecosystem services, affecting the provision and regulation services. Drivers that act on the system and induce negative impacts must develop responses, mainly in technological development, because of the need for adapting to a more restricted and uncertain supply of ecosystem services.

Thus, the methodology of this environmental description conceptual framework contributes to the selection of indicators and ecosystem services involved, and it can aid in the promotion of sustainability, providing subsidies for moreadequate environmental policies obtained from indicators that reflect local conditions.

\section{Acknowledgments}

This report was written during the concession of the scholarship from the Coordenação de Aperfeiçoamento de Pessoal do Nível Superior (CAPES) at the Federal University of Santa Maria (UFSM). The authors thank the SA-SuAve project of the Embrapa Suínos e Aves for providing the study data.

\section{References}

Borja, A., Elliott, M., Handersen, J. H., Berg, B., Carstense, J., Halpern, B. S.,... Rodriguez-Ezpeleta, N. (2016). Overview of integrative assessment of marine systems: the ecosystem approach in practice. Marine Ecosystem Ecology, 3(20), 1-20. doi: 10.3389/fmars.2016.00020

Burkhard, B., \& Müller, F. (2008). Drivers-pressurestate-impact-response. Ecological Indicators, 2, 967-970. doi: 10.1016/B978-008045405-4.00129-4

Burkhard, B., De Groot, R., Costanza, R., Seppelt, R., Jørgensen, S. E., \& Potschin, M. (2012b). Solutions for sustaining natural capital and ecosystem services. Ecological Indicator, 21, 1-6. doi: 10.1016/j. ecolind.2012.03.008

Burkhard, B., Kroll, F., Nedkov, S., \& Müller, F. (2012a). Mapping supply, demand and budgets of ecosystem services. Ecological Indicators, 21, 17-29. doi: 10.1016/j.ecolind.2011.06.019

Costanza, R., Arge, R., De Groot, F. S., Grasso, M., Hannon, B.,... Belt, M. (1997). The value of the world's ecosystem services and natural capital. Nature, 387, 253-260. doi: 10.1016/S09218009(98)00020-2 
Dale, V. H., \& Polasky, S. (2007). Measures of the effects of agricultural practices on ecosystem services. Ecological Economics, 64(2), 286-296. doi: 10.1016/j.ecolecon.2007.05.009

De Groot, R., Fisher, B., \& Christie, M. (2010). Integrating the ecological and economic dimensions in biodiversity and ecosystem service valuation. In P. Kumar (Ed.), The economics of ecosystems and biodiversity: ecological and economic foundations (Chap. 1, pp. 11-39). London: Earthscan.

Elliott, M. (2014). Integrated marine science and management: wading through the morass. Marine Pollution Bulletin, 86(1-2), 1-4. doi: 10.1016/j. marpolbul.2014.07.026

Fernandez-Lopez, M., López-González, D., PuigGamero, M., Valverde, J. L., \& Sanchez-Silva, L. (2016). $\mathrm{CO}_{2}$ gasification of dairy and swine manure: a life cycle assessment approach. Renewable Energy, 95, 552-560. doi: 10.1016/j.renene.2016.04.056

Fundação do Meio Ambiente (2014). Instrução Normativa 11. Santa Catarina, SC. Recuperado de http://www.fatma.sc.gov.br/index.php?option=com docman $\&$ task $=$ cat_view $\&$ gid $=32 \&$ Itemid $=83$

Gabrielson, P., \& Bosch, P. (2003). Environmental indicators: Typology and use in reporting. EEA internal working paper. Retrieved from http://www. brahmatwinn.uni-jena.de/fileadmin/Geoinformatik/ projekte/brahmatwinn/Workshops/FEEM/Indicators/ EEA_Working_paper_DPSIR.pdf

Gee, K., \& Burkhard, B. (2010). Cultural ecosystem services in the context of offshore wind farming: a case study from the west coast of SchleswigHolstein. Ecological Complexity, 7(3), 349-358. doi: 10.1016/j. ecocom.2010.02.008

Gómez, C. M., Delacámara, G., Jähnig, S., Langhans, S. D., Domisch S., Hermoso, V.,... O'Higgins, T. (2016). Developing the AQUACROSS assessment framework: Deliverable 3.2. Berlim. Retrieved from https://aquacross.eu/sites/default/files/D3.2_ Assessment\%20Framework.13012017.pdf

Haines-Young, R., \& Potschin, M. (2018). Common international classification of ecosystem services (CICES) V5.1: Guidance on the application of the revised structure. Nottingham. Retrieved from http:// www.cices.eu

Instituto Brasileiro de Geografia e Estatística (2018). Áreas dos Munícipios. Recuperado de https://www. ibge.gov.br/geociencias-novoportal/organizacaodo-territorio/estrutura-territorial/15761-areas-dosmunicipios.html? $=\& \mathrm{t}=\mathrm{o}$-que-e
Kandziora, M., Burkhard, B., \& Müller, F. (2013). Interactions of ecosystem properties, ecosystem integrity and ecosystem service indicators - a theoretical matrix exercise. Ecological Indicators, 28, 54-78. doi: 10.1016/j.ecolind.2012.09.006

Kelble, C. R., Loomis, D. K., Lovelace, S., Nuttle, W. K., Ortner, P. B., Fletcher, P.,... Boyer, J. N. (2013). The EBM-DPSER conceptual model: Integrating ecosystem services into the DPSIR framework. PLoS ONE, 8(8). doi: 10.1371/journal.pone.0070766

Koschke, L., Fürst, C., Frank, S., \& Makeschin, F. (2012). A multi-criteria approach for an integrated land-cover-based assessment of ecosystem services provision to support landscape planning. Ecological Indicators, 21, 54-66. doi: 10.1016/j. ecolind.2011.12.010

Kristensen, P. (2004). The DPSIR framework. Paper presented at the workshop on a comprehensivel detailed assessment of the vulnerability of water resources to environmental change in Africa using river basin approach. Nairobi, Kenya. Retrieved from http://wwz.ifremer.fr/dce/content/ download/69291/913220/ file/DPSIR.pdf.

La Notte, A., D’Amato, D., Mäkinen, H., Paracchini, M. L., Liquete, C., Egoh, B.,... Crossman, N. D. (2017). Ecosystem services classification: a systems ecology perspective of the cascade framework. Ecological Indicators, 74, 392-402. doi: 10.1016/j. ecolind.2016.11.030

Lewison, R. L., Rudd, M. A., Al-Hayek, W., Baldwin, C., Beger, M., Lieske, S. N.,... Hines, E. (2016). How the DPSIR framework can be used for structuring problems and facilitating empirical research in coastal systems. Environmental Science \& Policy, 56, 110-119. doi: 10.1016/j.envsci.2015.11.001

Maes, J., Liquete, C., Teller, A., Erhard, M., Paracchini, M. L., Barredo, J. I.,... Lavalle, C. (2016). An indicator framework for assessing ecosystem services in support of the EU Biodiversity Strategy to 2020. Ecosystem Services, 17, 14-23. doi: 10.1016/j. ecoser.2015.10.023

Martin, D. M., Piscopo, A. N., Chintala, M. M., Gleason, T. R., \& Berry, W. J. (2018). Developing qualitative ecosystem service relationships with the driverpressure-state-impact-response framework: A case study on Cape Cod, Massachusetts. Ecological Indicator, 84, 404-415. doi: 10.1016/j.ecolind. 2017.08.047

Miele, M., \& Waquil, P. D. (2007). Estrutura e dinâmica dos contratos na suinocultura de Santa Catarina: um 
estudo de casos múltiplos. Estudos Econômicos, 37(4), 817-847. doi: 10.1590/S0101-416120070004 00005

Müller, F., \& Burkhard, B. (2012). The indicator side of ecosystem services. Ecosystem Services, 1, 26-30. doi: 10.1016/j.ecoser.2012.06.001

Niemeijer, D., \& De Groot, R. (2008a). Framing environmental indicators: moving from causal chains to causal networks. Environment, Development and Sustainability, 10(1), 89-106. doi: 10.1007/s10668006-9040-9

Niemeijer, D., \& De Groot, R. (2008b). A conceptual framework for selecting environ-mental indicator sets. Ecological Indicators, 8(1), 14-25. doi: 10.1016/j.ecolind.2006.11.012

Omann, I., Stocker, A., \& Jäger, J. (2009). Climate change as a threat to biodiversity: an application of the DPSIR approach. Ecological Economics, 69(1), 24-31. doi: 10.1016/j.ecolecon.2009.01.003

Oudart, D., Robin, P., Paillat, J. M., \& Paul, E. (2015). Modelling nitrogen and carbon interactions in composting of animal manure in naturally aerated piles. Waste Management, 46, 588-598. doi: 10.1016/ j.wasman.2015.07.044

SA-SuAve (2018). Avaliação de indicadores $e$ estratégias para valoração de serviços ambientais em bacias hidrográficas com produção intensiva de animais. Concórdia: EMBRAPA Suínos e Aves.
Recuperado de https:/www.embrapa.br/suinos-eaves/busca-de-projetos/-/projeto/210482/avaliacaode-indicadores-e-estrategias-para-valoracao-deservicos-ambientais- em-bacias-hidrograficas-comproducao-intensiva-de-animais

Scolozzi, R., Morri, E., \& Santolini, R. (2012). Delphibased change assessment in ecosystem service values to support strategic spatial planning in Italian landscapes. Ecological Indicators, 21, 134-144. doi: 10. 1016/j.ecolind.2011.07.019

Smeets, E., \& Weterings, R. (1999). Environmental indicators: typology and overview. Technical Report no. 25. Copenhagen. Retrieved from http://www.eea. europa.eu/publications/TEC25

Svarstad, H., Petersen, L. K., Rothman, D., Siepel, H., \& Wätzold, F. (2008). Discursive biases of the environmental research framework DPSIR. Land Use Policy, 25(3), 116-125. doi: 10.1016/j. landusepol. 2007.03.005

Von Bertalanffy, L. (2015). Teoria geral dos sistemas: fundamentos, desenvolvimento aplicações (8nd ed.). Petropolis, RJ: Vozes.

Zhou, S., Mueller, F., Burkhard, B., Cao, X., \& Hou, Y. (2013). Assessing agricultural sustainable development based on the Dpsir approach: case study in Jiangsu, China. Journal of Integrative Agriculture, 12(7), 1292-1299. doi: 10.1016/S20953119(13)60434-7 